\title{
DESIGNING BERM BREAKWATERS FOR DIFFERENT WAVE HEIGHTS AND DIFFERENT QUARRY YIELD
}

\author{
Sigurdur Sigurdarson ${ }^{1}$ and Jentsje van der Meer $^{2}$
}

\begin{abstract}
The paper demonstrates the use of the geometrical design rules for berm breakwaters in a potential project in Greenland. With practically no information about the sizes of armourstone that could be used for the design, the initial phase of the study looked at the full range of the stability parameter $H_{s} / \Delta D_{n 50}$ of 1.7 to 3.0 for the design wave height of $\mathrm{H}_{\mathrm{s}}=4.4 \mathrm{~m}$. This corresponds to armourstone classes ranging from 5-15 t down to 1-3 t. Six different design options based on six different options for the largest stone class are compared. The final design then relies on the actual quarry yield, the total volume of material needed for the project and the construction equipment that can be brought to the site.
\end{abstract}

Keywords: berm breakwater; geometrical design; berm recession; wave overtopping; crest level, berm level

\section{INTRODUCTION}

The design of modern berm breakwaters started in the early eighties in Canada with Baird and Hall being originators. The original design consisted of mass armoured berms that were reshaped to statically stable S-shaped slopes. The basic principle was to use locally available materials and that the thickness of the armour layer was determined by the size of available armourstone, smaller stones required larger thickness. The design was adopted in Iceland and developed through a number of breakwater projects and eventually led to a development with more stable structures by utilizing available rock sizes, large rock and more gradings. This more stable and only partly reshaping structure is called the Icelandic-type berm breakwater.

Real guidance on design and construction of berm breakwaters has been lacking until the present authors started their cooperation, both in the scientific as well as the practical field. This has resulted in a new book of both authors, Design and Construction of Berm Breakwaters, which may be seen as an improvement on this (Van der Meer and Sigurdarson 2016). Aspects of this book have been presented at various conferences:

- New classification of berm breakwaters, (Sigurdarson and Van der Meer 2012)

- $\quad$ Recession, wave overtopping and reflection, (Sigurdarson and Van der Meer 2013)

- Geometrical design of the cross-section, (Van der Meer and Sigurdarson 2014)

- Application of geometrical design rules, (Sigurdarson et al. 2014)

- Quarries and rock grading, (Sigurdarson and Van der Meer 2015)

After briefly presenting the classification of berm breakwaters and the geometrical design formulae the paper gives examples of design based on different armourstone classes. Availability of rock and utilisation of quarried material is essential in the design of berm breakwaters. Often dedicated quarries can be found and/or opened to produce the required rock matching the design conditions. In many cases, it has been proven possible to produce extra-large armourstone in dedicated quarries and utilise in the design. Examples of this has been described in the previously mention book by the authors. Quarry and project management as well as blasting and sorting techniques are essential in getting all required rock for an acceptable price.

Berm breakwaters may be an alternative for conventional two-layer rock slopes as well as for application of concrete units. It depends mainly on rock availability and design wave conditions.

\section{Classification of berm breakwaters}

Berm breakwaters can be divided into hardly reshaping (HR), partly reshaping (PR) and fully reshaping (FR), all depending on the stability number for the (100-years) design condition, $\mathrm{H}_{\mathrm{sD}}$. A berm breakwater can be designed as a mass armoured berm breakwater (MA) or an Icelandic-type berm breakwater. The classification of berm breakwaters given in Table 1 is based on the stability number $\mathrm{H}_{\mathrm{s}} / \Delta \mathrm{D}_{\mathrm{n} 50}$ and takes into account the structural behaviour including the degree of reshaping. $\mathrm{S}_{\mathrm{d}}$ is the damage number and Rec the expected recession of the berm.

\footnotetext{
${ }^{1}$ IceBreak Consulting Engineers ehf, Reykjavik, Iceland / Icelandic Road and Coastal Authority, Reykjavik, Iceland

2 Van der Meer Consulting bv, Akkrum, The Netherlands / UNESCO-IHE, Delft, The Netherlands
} 


\begin{tabular}{|l|l|l|c|c|}
\hline \multicolumn{5}{|l|}{ Table 1. Classification of berm breakwaters. } \\
\hline Type of berm breakwater & $\begin{array}{c}\text { Abbreviatio } \\
\mathrm{n}\end{array}$ & $\mathrm{H}_{\mathrm{SD}} / \Delta \mathrm{D}_{\mathrm{n} 50}$ & $\mathrm{~S}_{\mathrm{d}}$ & $\mathrm{Rec} / \mathrm{D}_{\mathrm{n} 50}$ \\
\hline Hardly reshaping Icelandic-type berm breakwater & $\mathrm{HR}-\mathrm{IC}$ & $1.7-2.0$ & $2-8$ & $0.5-2$ \\
Partly reshaping Icelandic-type berm breakwater & PR-IC & $2.0-2.5$ & $10-20$ & $1-5$ \\
Partly reshaping mass armoured berm & PR-MA & $2.0-2.5$ & $10-20$ & $1-5$ \\
breakwater & FR-MA & $2.5-3.0$ & -- & $3-10$ \\
Reshaping mass armoured berm breakwater &
\end{tabular}

\section{GEOMETRICAL DESIGN GUIDANCE}

Front slope stability or recession

Sigurdarson and Van der Meer (2011) showed that the main parameter that describes the recession, Rec, is the stability number $\mathrm{H}_{\mathrm{s}} / \Delta \mathrm{D}_{\mathrm{n} 50}$. Recession up to the design condition, 100-years event, can be described with Eq. 1 which gives the average fit to the dataset used to define it.

$$
\operatorname{Rec} / \mathrm{D}_{\mathrm{n} 50}=1.6\left(\mathrm{H}_{\mathrm{s}} / \Delta \mathrm{D}_{\mathrm{n} 50}-1.0\right)^{2.5} \quad \text { with: } \mathrm{Rec} / \mathrm{D}_{\mathrm{n} 50}=0 \text { for } \mathrm{H}_{\mathrm{s}} / \Delta \mathrm{D}_{\mathrm{n} 50}<1.0(1)
$$

The formula shows that for a statically stable Icelandic-type berm breakwater with a design value of $\mathrm{H}_{\mathrm{sD}} / \Delta \mathrm{D}_{\mathrm{n} 50}=1.7$ to 2.0 the expected recession is not more than about 0.7 to 1.6 stone diameters. For a partly reshaping berm breakwater with $\mathrm{H}_{\mathrm{sD}} / \Delta \mathrm{D}_{\mathrm{n} 50}=2.0$ to 2.5 this may increase to 1.6 to nearly 5 stone diameters, depending on how accurate the rock on the front slope has been placed. A fully reshaping mass armoured breakwater may have up to or more than 10 stone diameters reshaping.

But the data Eq. 1 is based on shows a large scatter and this is due to other parameters that influence the berm recession. Three geometrical parameters may have substantial influence on berm recession, the seaward down slope $\cot \alpha$, the berm level $\mathrm{d}_{\mathrm{B}} / \mathrm{H}_{\mathrm{sD}}$ and the presence of a toe berm at level $\mathrm{h}_{\mathrm{t}} / \mathrm{H}_{\mathrm{sD}}$. Deviation from an "average" geometry may lead to a negative score, if assumed less stable, or a positive score, if assumed more stable. The scoring system of Table 2 was made (see also Sigurdarson and Van der Meer 2011) and explains for a large part the scatter in different model test results. Note that the scoring with respect to the berm level $\mathrm{d}_{\mathrm{B}} / \mathrm{H}_{\mathrm{sD}}$ has been enhanced, compared to the table published earlier. A low berm gives a negative score, but a high berm a positive one.

\begin{tabular}{|c|c|c|c|}
\hline & Average dimension & \multicolumn{2}{|c|}{ Alternative and score } \\
\hline \multicolumn{4}{|l|}{ Hardly reshaping berm breakwaters HR } \\
\hline Down slope & $\operatorname{cota}_{d}=1.5$ & $\cot \alpha_{d}<1.5$ & - \\
\hline \multirow[t]{2}{*}{ Berm level } & $0.5<\mathrm{d}_{\mathrm{B}} / \mathrm{H}_{\mathrm{SD}}<0.6$ & $\mathrm{~d}_{\mathrm{B}} / \mathrm{H}_{\mathrm{SD}}<0.5$ & - \\
\hline & & $\mathrm{d}_{\mathrm{B}} / \mathrm{H}_{\mathrm{SD}} \geq 0.6$ & + \\
\hline Toe depth & \multicolumn{3}{|c|}{$\mathrm{h}_{\mathrm{t}} / \mathrm{H}_{\mathrm{SD}}$ : no influence (hardly any reshaping) } \\
\hline \multicolumn{4}{|l|}{ Partly reshaping berm breakwaters PR } \\
\hline Down slope & $\cot \alpha_{d}=1.5$ & $\operatorname{cota}_{d}<1.5$ & - \\
\hline \multirow[t]{2}{*}{ Berm level } & $0.5<\mathrm{d}_{\mathrm{B}} / \mathrm{H}_{\mathrm{SD}}<0.6$ & $\mathrm{~d}_{\mathrm{B}} / \mathrm{H}_{\mathrm{SD}}<0.5$ & - \\
\hline & & $\mathrm{d}_{\mathrm{B}} / \mathrm{H}_{\mathrm{SD}} \geq 0.6$ & + \\
\hline \multirow[t]{3}{*}{ Toe depth } & $2.0<\mathrm{h}_{\mathrm{t}} / \mathrm{H}_{\mathrm{sD}} \leq 2.5$ & $h_{t} / H_{s D}>2.5$ & - \\
\hline & & $1.6<h_{t} / H_{S D} \leq 2.0$ & + \\
\hline & & $\mathrm{h}_{\mathrm{t}} / \mathrm{H}_{\mathrm{sD}} \leq 1.6$ & ++ \\
\hline \multicolumn{4}{|l|}{ Fully reshaping berm breakwaters FR } \\
\hline \multirow[t]{2}{*}{ Down slope } & $\cot \alpha_{d}=1.25 / 1.33$ & $\operatorname{cota}_{d}<1.25$ & - \\
\hline & & $\operatorname{cota}_{d}>1.33$ & + \\
\hline \multirow[t]{2}{*}{ Berm level } & $0.5<\mathrm{d}_{\mathrm{B}} / \mathrm{H}_{\mathrm{SD}}<0.6$ & $\mathrm{~d}_{\mathrm{B}} / \mathrm{H}_{\mathrm{SD}}<0.5$ & - \\
\hline & & $\mathrm{d}_{\mathrm{B}} / \mathrm{H}_{\mathrm{SD}} \geq 0.6$ & + \\
\hline \multirow[t]{3}{*}{ Toe depth } & $2.0<\mathrm{h}_{\mathrm{t}} / \mathrm{H}_{\mathrm{sD}} \leq 2.5$ & $h_{t} / H_{s D}>2.5$ & - \\
\hline & & $1.6<\mathrm{h}_{\mathrm{t}} / \mathrm{H}_{\mathrm{SD}} \leq 2.0$ & + \\
\hline & & $\mathrm{h}_{\mathrm{t}} / \mathrm{H}_{\mathrm{sD}} \leq 1.6$ & ++ \\
\hline
\end{tabular}

Above points are of course very useful when designing a berm breakwater. Eq. 1 gives the average expected recession, but this may be changed to a more stable breakwater by adapting the design parameters of Table 2 in a positive way. 


\section{Wave overtopping}

Wave overtopping at a berm breakwater is given by the general formula in EurOtop [2016], with an adapted influence factor $\gamma_{\mathrm{BB}}$ for berm breakwaters:

$$
\frac{q}{\sqrt{g \cdot H_{m 0}^{3}}}=0.09 \cdot \exp \left[-\left(1.5 \frac{R_{c}}{H_{m 0} \cdot \gamma_{B B} \cdot \gamma_{\beta}}\right)^{1.3}\right]
$$

with:

$$
\begin{array}{lr}
\gamma_{\mathrm{BB}}=0.68-4.5 \mathrm{~s}_{\mathrm{op}}-0.05 \mathrm{~B} / \mathrm{H}_{\mathrm{SD}} & \text { for } \mathrm{HR} \text { and } \mathrm{PR} \\
\gamma_{\mathrm{BB}}=0.70-9.0 \mathrm{~s}_{\mathrm{op}} & \text { for FR }
\end{array}
$$

and $\mathrm{B} / \mathrm{H}_{\mathrm{sD}}$ is given by the design wave height. Here $\mathrm{s}_{\mathrm{op}}$ is the fictitious deep water wave steepness, using the peak period, $T_{p}$, and the significant wave height, $H_{m 0}$, at the toe of the structure. $B=$ berm width. This new EurOtop formula for berm breakwaters slightly differs from that presented in the book on berm breakwaters.

\section{Cross-sectional parameters}

The main geometrical design parameters of the Icelandic-type berm breakwater are shown in Figure 1. It assumes the usage of four armourstone classes of different sizes plus core material that usually consists of quarry run. Depending on the design wave conditions and availability of rock often less armourstone classes are used, as will be the case in the example presented later in this paper.

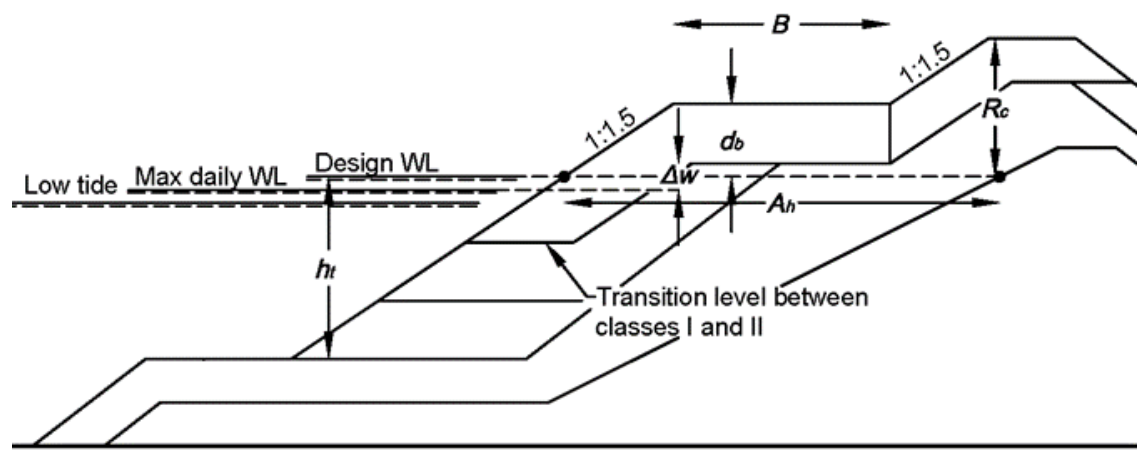

Figure 1. Geometrical design parameters of the Icelandic-type berm breakwater.

A berm breakwater has an upper slope and a down slope, with a berm in between. In the initial design, it is practical to choose both slopes with $\cot \alpha=1.5$. The main horizontal parameters are firstly the berm width, $\mathrm{B}$, and secondly the horizontal armour width, $\mathrm{A}_{\mathrm{h}}$. In addition to this are the crest width and toe berm width.

The vertical parameters use different reference levels. The crest height, $\mathrm{R}_{\mathrm{c}}$, is measured from the design water level, DWL. The same goes for the berm height, $\mathrm{d}_{\mathrm{b}}$. and the level of toe berm or apron, $\mathrm{h}_{\mathrm{t}}$. For practical construction purposes a working level for the construction of the berm is chosen as $\Delta \mathrm{w}$ above the daily maximum water level and in the case of an Icelandic-type berm breakwater this level may influence the final berm level.

Most of the geometrical design parameters will not be covered in this paper and reference is made to Van der Meer and Sigurdarson 2016. As the examples of application of the design rules presented in this paper will show the interconnection of the berm width, $\mathrm{B}$, and the horizontal armour width, $\mathrm{A}_{\mathrm{h}}$, these parameters will be described further.

\section{Berm width as a function of recession and resiliency}

The crest height, $\mathrm{R}_{\mathrm{c}}$, should be designed to a certain level, depending on the allowable wave overtopping at the design water level using Eq. 2 to 4. 
The choice of berm width, B, depends on the classification of the expected structural behavior, hardly, partly or fully reshaping. With lower stability number of the main armourstone class, the more stable the structure will be, with less recession. The expected recession influences the choice of berm width which should be chosen larger than the expected recession. Although less recession should not be the only objective of designing the berm width, it results in larger capacity to cope with extremes. The capability of coping with extremes, the resiliency of the structure, should play a role in designing the berm width.

The berm width is determined from both resiliency and from geometry. The resiliency of the berm breakwater decreases with increasing stability number. It is proposed to consider the following guidelines on resiliency, given in Eq. 5 to 7, connecting expected recession, Rec, and required berm width, B. The resiliency is given as a percentage, $\mathrm{P} \%$, of the berm width that may erode under the design condition $\mathrm{H}_{\mathrm{SD}}$. For a fully reshaping structure the percentage should not be $100 \%$ as the percentage is given for the design conditions only. Overload conditions larger than the 100-years condition may take more from the berm.

The choice of $\mathrm{P} \%$ has to be made by designer and client, where a lower limit can be taken for more safety, but also for a larger and costlier berm. The values given in Eq. 5 to 7 are best guesses based on experience. After having more experience with designing according to these explicit guidelines, they should be evaluated and possibly modified.

$\begin{array}{llll}\text { Very resilient } & \text { hardly reshaping, } & \text { IC HR } & \mathrm{P} \%=10-20 \% \\ \text { Good resiliency } & \text { partly reshaping, } & \text { IC PR or MA PR } & \mathrm{P} \%=20-40 \% \\ \text { Minimum resiliency } & \text { fully reshaping, } & \text { MA FR } & \mathrm{P} \% \leq 70 \%\end{array}$

Consequently, if the wanted resiliency has been chosen, the berm width based on resiliency becomes:

$$
\mathrm{B}=\operatorname{Rec} /(\mathrm{P} \% / 100)
$$

In addition to the cope with the wanted resiliency, there is a geometrical criterion for the berm width. As Class I rock of an Icelandic type of berm breakwater may be quite large, the berm width is very often close to 3 to $4 D_{n 50}$. A rule for a minimum berm width could be:

$$
B_{\min }=R e c+1 D_{n 50} \text { with a minimum of at least } 3 D_{n 50}
$$

\section{Horizontal armour width}

While the berm width is a part of the outward dimensions of the berm breakwater the horizontal armour width, $A_{h}$, is a part of the inward dimensions. It determines the total thickness of the armour, rather narrowly graded armour with relatively high void ratio that is needed to swallow up the wave when breaking on the structure. The horizontal armour width is measured at design water level from the seaward slope of the armour to the transition of sorted rock class to the core. The good structural behaviour of berm breakwaters is for a large part due to the large capacity of dissipating wave energy in the large berm. A class of sorted rock gives large voids between the stones and this causes the dissipating capacity. For this reason, the horizontal width of the armour at design water level should not become too small. It has always been an implicit but important parameter in design and development of the Icelandic type berm breakwater.

By analyzing a number of berm breakwaters that had been designed and constructed in Iceland and Norway over the period of 1983 to 2008 Van der Meer and Sigurdarson, 2014, plotted the horizontal armour width, $A_{h}$, versus the stability number, $H_{s} / \Delta D_{n 50}$. This analysis leads to a design rule for the horizontal armour width parameter, which is valid for hardly and partly reshaping berm breakwaters, but as well for fully reshaping mass armoured berm breakwaters:

$$
\mathrm{A}_{\mathrm{h}} / \mathrm{H}_{\mathrm{sD}}=2 \mathrm{H}_{\mathrm{sD}} / \Delta \mathrm{D}_{\mathrm{n} 50}
$$

The horizontal armour width $A_{h}$ depends linearly on the stability number. Hardly reshaping structures would give $A_{h}=3.4$ to $4.0 \mathrm{H}_{\mathrm{sD}}$, partly reshaping structures to $A_{h}=4.0$ to $5.0 \mathrm{H}_{\mathrm{sD}}$ and fully reshaping berm breakwaters to $A_{h}=5.0$ to $6.0 \mathrm{H}_{\mathrm{sD}}$, taking into account the classification given in Table 1. 


\section{APPLICATION OF THE DESIGN RULES}

\section{Project in Greenland}

Recently the geometrical design rules for berm breakwaters (Van der Meer and Sigurdarson 2016) have been applied in a feasibility study for a potential project in Greenland and used to make conceptual design options for a berm revetment.

The location of the project is deep in a fjord and sheltered for ocean waves. In present climate, the fjord is covered with ice large part of the year during which time it is not subjected to wave load. Limited statistical information about the ice conditions were provided, but according to literature the ice-free period has often been very short or only in August and September. To make allowances for uncertainties and possible changes due to global warming it was decided to base the wind and wave analysis on the period from May to November.

Analysis of two about 30 years long wind records shows that majority of the measurements above thresholds 10, 15 and $20 \mathrm{~m} / \mathrm{s}$ come from directions that will not generate waves confronting the revetment structure. Therefore, the wind analysis was based on a rather narrow directional sector but still chosen wider than the actual open sector to be on the safe side. Based on all year data from one of the two weather stations the wind velocity with 10 -year return period is $21 \mathrm{~m} / \mathrm{s}$ and with 100 -year return period $25 \mathrm{~m} / \mathrm{s}$. For the period of May to November the results are slightly lower, or 17 and $24 \mathrm{~m} / \mathrm{s}$ for the 10 and 100 years return periods respectively. For the other wind record the results are similar but slightly higher with the 10 and 100-year wind velocity for the period May to November 22 and $26 \mathrm{~m} / \mathrm{s}$ respectively.

In the first phase of the study the design wave height was established with simple methods based on effective fetch resulting in a design wave height of $\mathrm{H}_{\mathrm{s}}=4.4 \mathrm{~m}$ with a peak period of about $\mathrm{T}_{\mathrm{p}}=8 \mathrm{~s}$. In later phases of the project more advanced models were used to determine the design wave conditions. This resulted in a lower design wave height but for the sake of demonstrating the geometrical design rules the initially established wave conditions will be used.

The tidal range is the microtidal range with a mean spring tidal difference of about $1.2 \mathrm{~m}$. The design high water level, which practically only included astronomical tides and barometric setup as there is neither wind nor wave set-up at the location, was determined $0.8 \mathrm{~m}$ above mean high water spring tide.

It is anticipated that a dedicated armourstone quarry would be opened for the project. But with practically no information about type or quality of available rock for quarrying various design options were considered. These included the options that the largest class of armourstone, Class I, would consist of armourstone ranging from 1-3 to 5-15 t. The six possible armourstone classes are listed in Table 3. For the initial design wave height of $\mathrm{H}_{\mathrm{sD}}=4.4 \mathrm{~m}$, this corresponds to designs with a stability parameter $\mathrm{H}_{\mathrm{sD}} / \Delta \mathrm{D}_{\mathrm{n} 50}$ of about 3.0 down to 1.7 covering the whole range of berm breakwaters, see Table 1. By applying the geometrical design rules for armourstone classes with different stability parameters, it was possible to present different designs. For the small stones with high stability parameter the resulting design was more voluminous than for large stones with low stability parameter.

When designing a berm structure, breakwater with or without a road or a quay on the lee side or a revetment protecting a landfill, the designer must be aware if it is the outer or inner dimensions that determine the total volume of the structure. The outer dimensions are the inner slope, crest width, upper front slope, berm width and the lower front slope. The inner dimensions are the horizontal armour width, $A_{h}$, and the required width of core for construction of the breakwater.

The horizontal armour width is directly determined from the design wave height and stability number, Eq. 10. As seen in Table 3 the horizontal armour width varies from $16 \mathrm{~m}$ for the heaviest stone class of 5-15 t to $27 \mathrm{~m}$ for the lightest stone class of 1-3 $\mathrm{t}$.

As earlier stated the berm width, B, is determined both from resiliency and geometry. For the crosssections looked at in this project it is the resiliency that is determining. The expected percentage of the berm width, $\mathrm{P} \%$, that may erode under the design conditions was chosen within the limits presented in Eq. 5 to 7. For the heaviest stone class representing a hardly reshaping berm breakwater P\% was chosen as $10 \%$ but for the lightest class representing a mass armoured structure P\% was chosen as $69 \%$. This resulted in a berm width, $\mathrm{B}$, equal to $12 \mathrm{~m}$ for all design options, see Table 3 .

The berm level depends on two criteria. Firstly, the berm level preferably should be at least $0.6^{*} \mathrm{H}_{\mathrm{sD}}$ above the design water level. In such a case the recession will be decreased with respect to Eq. 1 according to the scoring system in Table 2. The second criterion is connected to the construction of the berm. It has proven to be practical to use a certain safety level, $\Delta \mathrm{w}$ above the maximum expected 
water level during the construction period, as a working level for excavators or cranes. The safety level $\Delta \mathrm{w}$ depends on the wave climate expected during the construction period. The berm is built up to its full width from this level, finishing with adding two rows of Class I stones on top of it.

For the project in Greenland the first criterion is determining for berm level for five of the six design options. For low wave activity $\Delta \mathrm{w}$ was chosen as $0.5 \mathrm{~m}$ resulting in a berm level of $+4.7 \mathrm{~m}$. Only for the largest stone class the berm level needs to be slightly higher or $+4.8 \mathrm{~m}$, see Table 3 .

With given overtopping criteria for yearly conditions, 100-year conditions as well as for overload, the crest level is determined with Eqs. 2 to 5 . This results in a lower crest level for the fully reshaping design options and higher crest level for the hardly reshaping structures. The difference may be due to the more gentle reshaped profile for the fully reshaping structure, as a gentle slope gives less overtopping. As seen in Table 3 the crest height varies from +6.9 to $7.7 \mathrm{~m}$.

\begin{tabular}{|c|c|c|c|c|c|c|}
\hline Class I & $\begin{array}{c}\text { Stability number } \\
H_{S} / \Delta D_{n 50}\end{array}$ & $\begin{array}{c}\text { Armour width } \\
A_{h}(m)\end{array}$ & $\begin{array}{c}\text { Resiliency } \\
\text { P\% (\%) }\end{array}$ & $\begin{array}{l}\text { Berm width } \\
\text { B (m) }\end{array}$ & $\begin{array}{c}\text { Berm level } \\
B_{\mid}(m)\end{array}$ & $\begin{array}{c}\text { Crest level } \\
\mathrm{C}_{l}(\mathrm{~m})\end{array}$ \\
\hline $5-15 t$ & 1.74 & 16 & $10 \%$ & 12 & 4.8 & 7.7 \\
\hline $4-12 t$ & 1.87 & 17 & $14 \%$ & 12 & 4.7 & 7.7 \\
\hline $3-9 t$ & 2.06 & 19 & $21 \%$ & 12 & 4.7 & 7.7 \\
\hline $2-6 \mathrm{t}$ & 2.36 & 21 & $34 \%$ & 12 & 4.7 & 7.5 \\
\hline $1.5-4.5 \mathrm{t}$ & 2.60 & 23 & $46 \%$ & 12 & 4.7 & 6.9 \\
\hline $1-3 t$ & 2.98 & 27 & $69 \%$ & 12 & 4.7 & 6.9 \\
\hline
\end{tabular}

Berm breakwater cross-sections for the different design options are shown in Figure 2. The expected reshaped profile after the design conditions have been reached, is shown on each crosssection. On top is a hardly reshaping cross-section based on Class I of 5-15 $t$ and on the bottom a fully reshaping cross-section based on Class I of 1-3 t.

As these cross-sections are drawn the outer dimensions are determining for the total cross-sectional volume. As the horizontal armour width, $A_{h}$, increases from top to bottom on Figure 2, the transition between core of quarry run and armourstone classes moves inward in the structure. The limit would be that the width of the core needs to be wide enough for construction purposes. Therefore, the total volume of the structure doesn't increase although the armour width increases. In this case, it is the opposite. As the crest level is higher for the hardly reshaping structure compared to the fully reshaping, the total cross-sectional volume is slightly higher for the hardly reshaping, see Table 4.

On the other hand, the total cross-sectional volume of armourstone is lower for the hardly reshaping structure compared to the fully reshaping structure. When we have come so far then it depends on the quarry which structure is more economical.

\begin{tabular}{|c|c|c|c|}
\hline $\begin{array}{c}\text { Armourstone } \\
\text { Class I }\end{array}$ & $\begin{array}{l}\text { Armourstone } \\
\left(\mathrm{m}^{3} / \mathrm{m}\right)\end{array}$ & $\begin{array}{l}\text { Core } \\
\left(\mathrm{m}^{3} / \mathrm{m}\right)\end{array}$ & $\begin{array}{l}\text { Total } \\
\left(\mathrm{m}^{3} / \mathrm{m}\right)\end{array}$ \\
\hline $5-15 \mathrm{t}$ & 240 & 610 & 850 \\
\hline $4-12 t$ & 250 & 600 & 850 \\
\hline $3-9 t$ & 270 & 580 & 850 \\
\hline $2-6 \mathrm{t}$ & 290 & 550 & 840 \\
\hline $1.5-4.5 \mathrm{t}$ & 310 & 500 & 810 \\
\hline $1-3 t$ & 350 & 460 & 810 \\
\hline
\end{tabular}

In this example the outer dimensions are determining for the total volume and therefore the cost of the structure. If the structure had not had a road on its lee side then it would not have been possible to move the transition between core and armour so far into the structure as was possible in this case. At some point the necessary width of the core for construction would have been reached and in that case the inner dimensions would have become determining. 

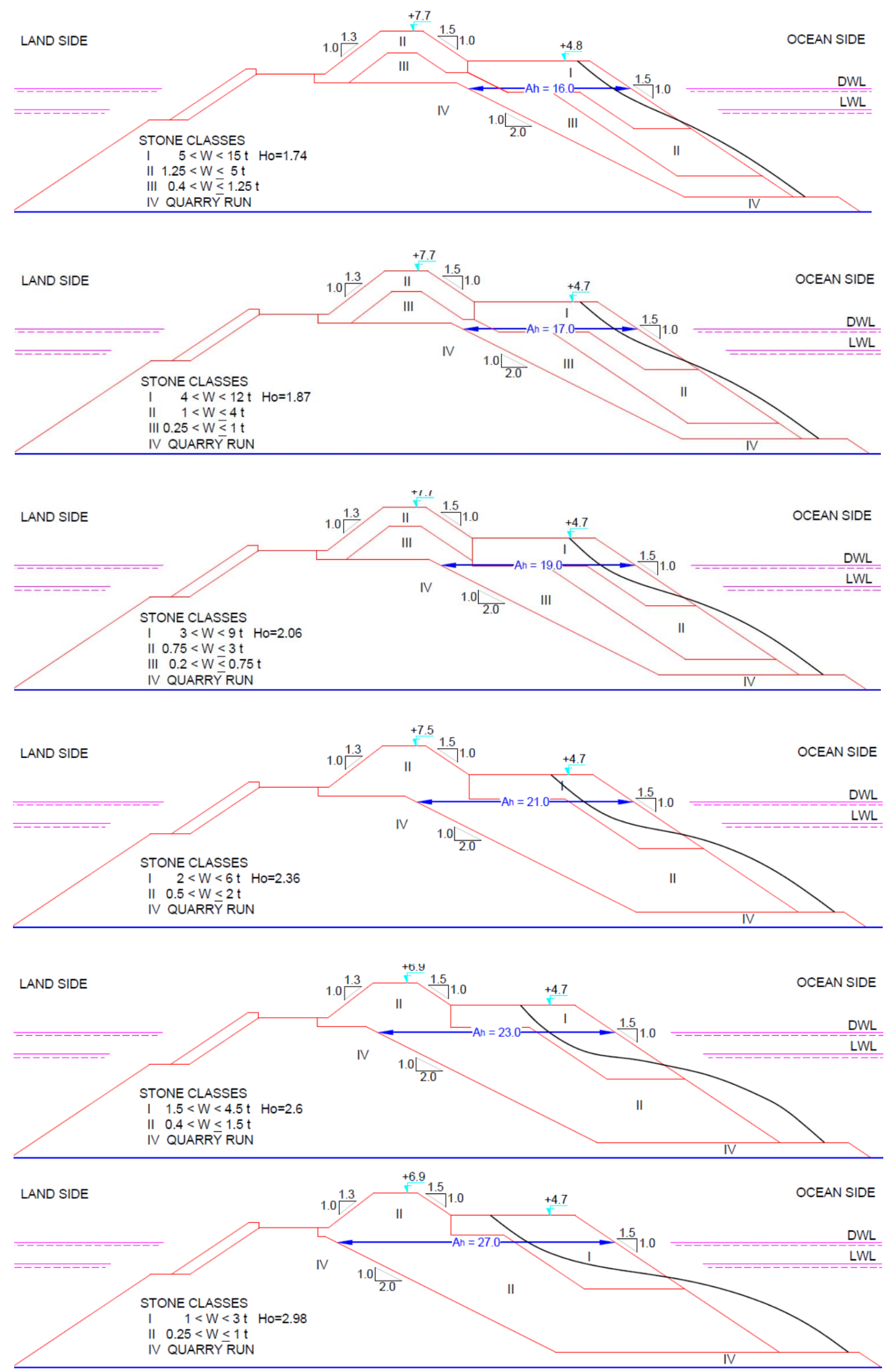

Figure 2. Berm breakwater cross-sections for different armourstone classes with the assumed reshaped profile. 
We will now take a closer look at the hardly reshaping cross-section based on the 5-15 $\mathrm{t}$ armourstone class. In the example above we did choose to base the berm width on $\mathrm{P} \%$ equal to $10 \%$, meaning that $10 \%$ of the berm width would erode during design conditions. But we had a choice between 10 and $20 \%$ according to Eq. 5 .

In Table 5 three options are listed with $\mathrm{P} \%$ equal to $10,12.5$ and $15 \%$ resulting in a berm width of 12,10 and $8 \mathrm{~m}$. All options fulfilling the minimum criteria of 3 to $4 * \mathrm{D}_{\mathrm{n} 50}$ and that after the 100 -year recession the remaining berm width should be at least $1 * D_{n 50}$. The reduction of the berm width has influence on the required crest level according to Eq. 3 , resulting in a crest level of $+7.7,+8.1$ and +8.4 $\mathrm{m}$ for the three options respectively.

Table 5. Stability number and design parameters for the different armourstone classes.
\begin{tabular}{|c|c|c|c|c|c|c|}
\hline $\begin{array}{c}\text { Armourstone } \\
\text { Class I }\end{array}$ & $\begin{array}{c}\text { Stability number } \\
\mathrm{H}_{\mathrm{S}} / \Delta \mathrm{D}_{\mathrm{n} 50}\end{array}$ & $\begin{array}{c}\text { Armour width } \\
\mathrm{A}_{\mathrm{h}}(\mathrm{m})\end{array}$ & $\begin{array}{c}\text { Resiliency } \\
\mathrm{P} \%(\%)\end{array}$ & $\begin{array}{c}\text { Berm width } \\
\mathrm{B}(\mathrm{m})\end{array}$ & $\begin{array}{c}\text { Berm level } \\
\mathrm{B}_{\mathrm{I}}(\mathrm{m})\end{array}$ & $\begin{array}{c}\text { Crest level } \\
\mathrm{C}_{\mathrm{I}}(\mathrm{m})\end{array}$ \\
\hline $5-15 \mathrm{t}$ & 1.74 & 16 & $10 \%$ & 12 & 4.8 & 7.7 \\
$5-15 \mathrm{t}$ & 1.74 & 16 & $12.5 \%$ & 10 & 4.8 & 8.1 \\
$5-15 \mathrm{t}$ & 1.74 & 16 & $15 \%$ & 8 & 4.8 & 8.4 \\
\hline
\end{tabular}

Berm breakwater cross-sections for the three different design options are shown in Figure 3 together with the expected reshaped profile after the design conditions have been reached.

As earlier stated for this structure the outer dimensions are determining for the total volume. The increase of $\mathrm{P} \%$ resulted in lesser berm width but higher cress level. The total effect on the volume is shown in Table 6. There is marginal increase of armourstone volume and a small decrease of core volume, resulting in a small decrease of the total volume.

\begin{tabular}{|c|c|c|c|c|}
\hline $\begin{array}{c}\text { Armourstone } \\
\text { Class I }\end{array}$ & $\begin{array}{l}\text { Berm width } \\
\text { B }(m)\end{array}$ & $\begin{array}{c}\text { Armourstone } \\
\left(\mathrm{m}^{3} / \mathrm{m}\right)\end{array}$ & $\begin{array}{l}\text { Core } \\
\left(m^{3} / m\right)\end{array}$ & $\begin{array}{l}\text { Total } \\
\left(\mathrm{m}^{3} / \mathrm{m}\right)\end{array}$ \\
\hline $5-15 t$ & 12 & 240 & 610 & 850 \\
\hline $5-15 t$ & 10 & 240 & 600 & 840 \\
\hline $5-15 t$ & 8 & 250 & 580 & 830 \\
\hline
\end{tabular}

As stated earlier, in the first phases of the study there was practically no information about what sizes of armourstone would be possible to quarry close to the project site. Later the design team was provided with photos that showed scattered loose rock on a hill side taken from some distance, Figure 4. But the problem was that there was no scale on the photos and therefore difficult to determine the sizes of the rock. It was not until the design team found photos with an adult polar bear running over the same hill side that is was possible with "some" likelihood to determine the rock sizes, Figure 5.

Based on this and more information that came available on later stages it was deemed highly likely that it would be possible to quarry armourstone with a yield of at least $10 \%$ over $1 \mathrm{t}$ and $5 \%$ over $2 \mathrm{t}$. Looking at the total volume of material that needed to be quarried from the dedicated armourstone quarry and the anticipated yield, the study concluded the largest stone class could be chosen as 2-6 t or even larger. 

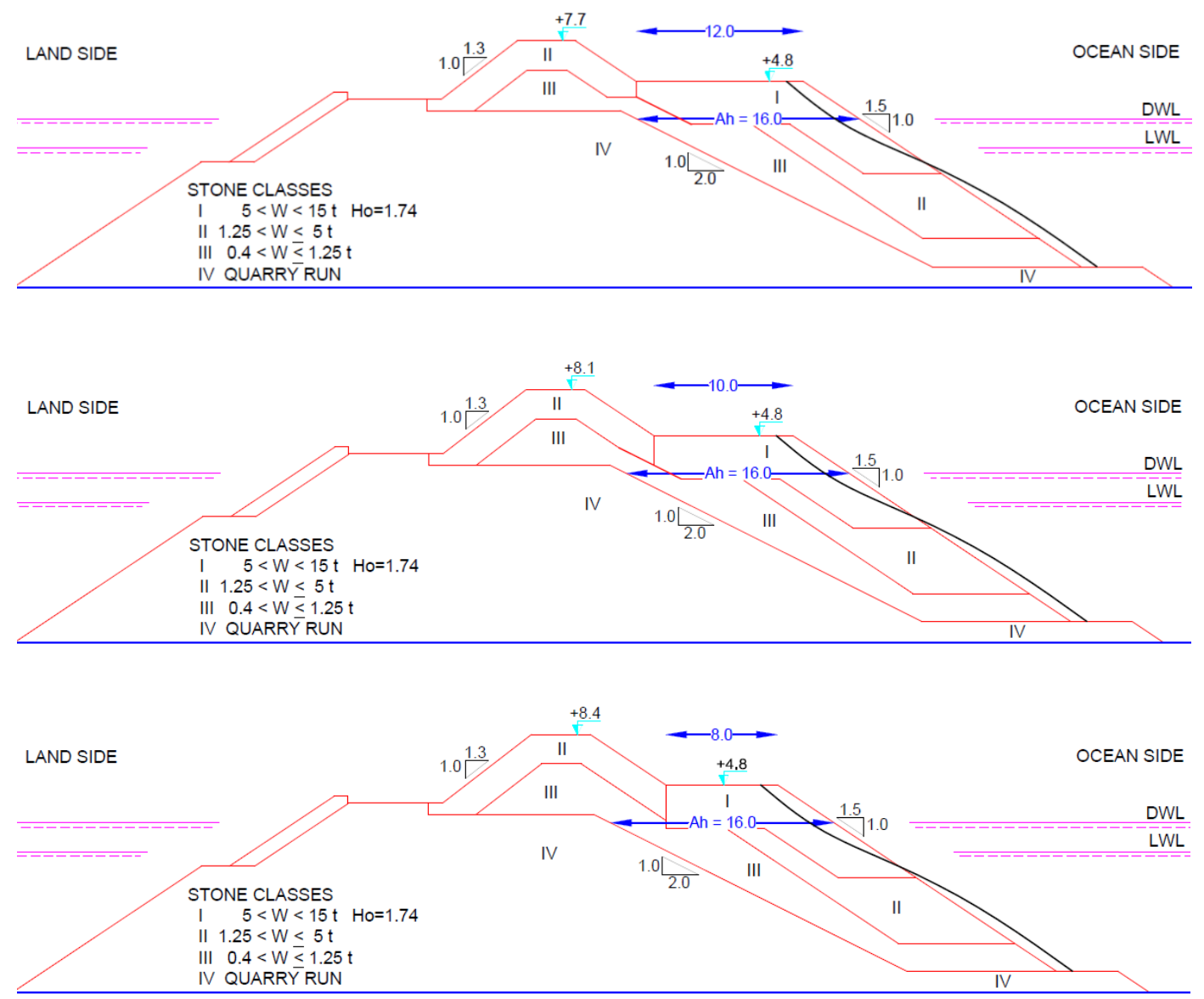

Figure 3. Berm breakwater cross-sections for the 5-15 $\mathrm{t}$ stone class with different choice of berm width.

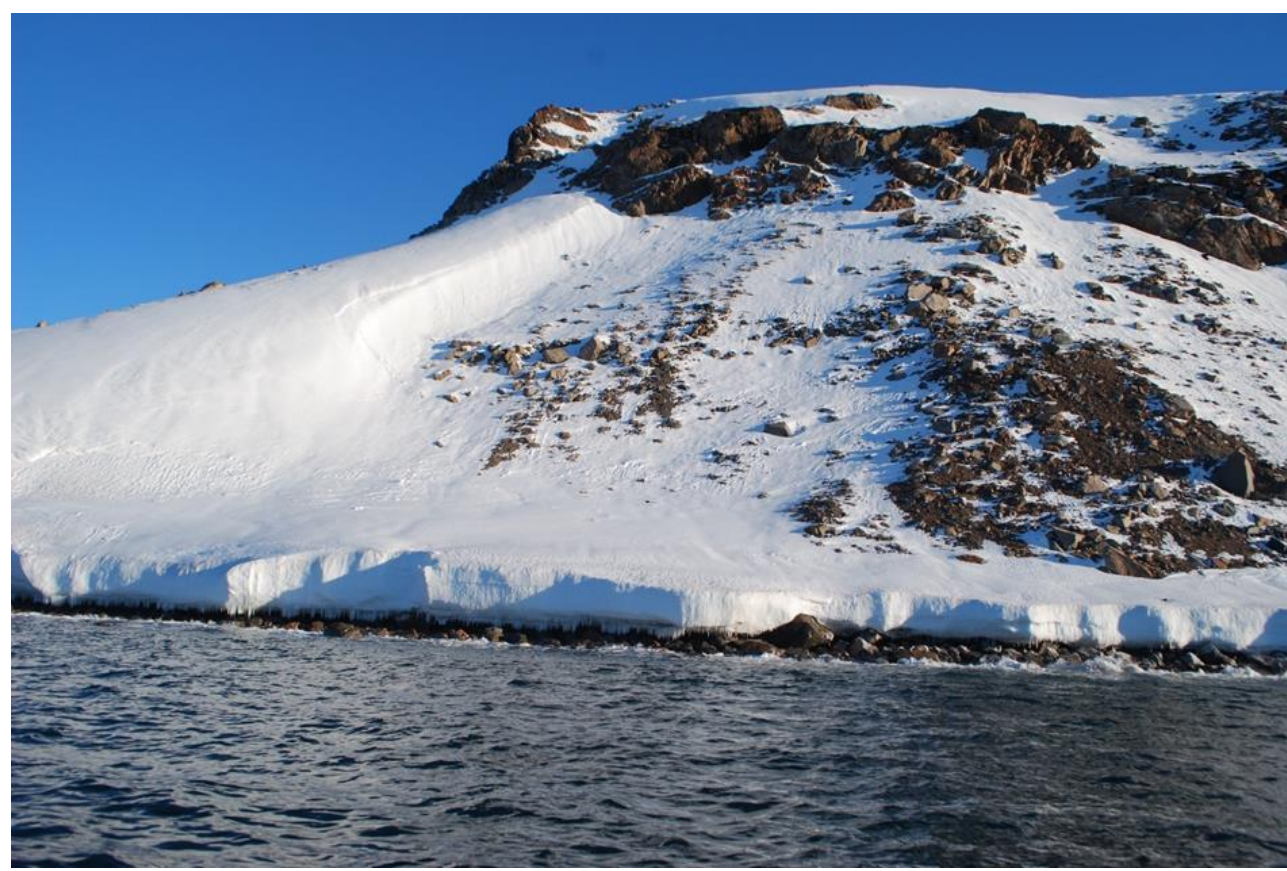

Figure 4. A mountain or hill close to the project site. Loose rocks can be seen but size is unknown. 


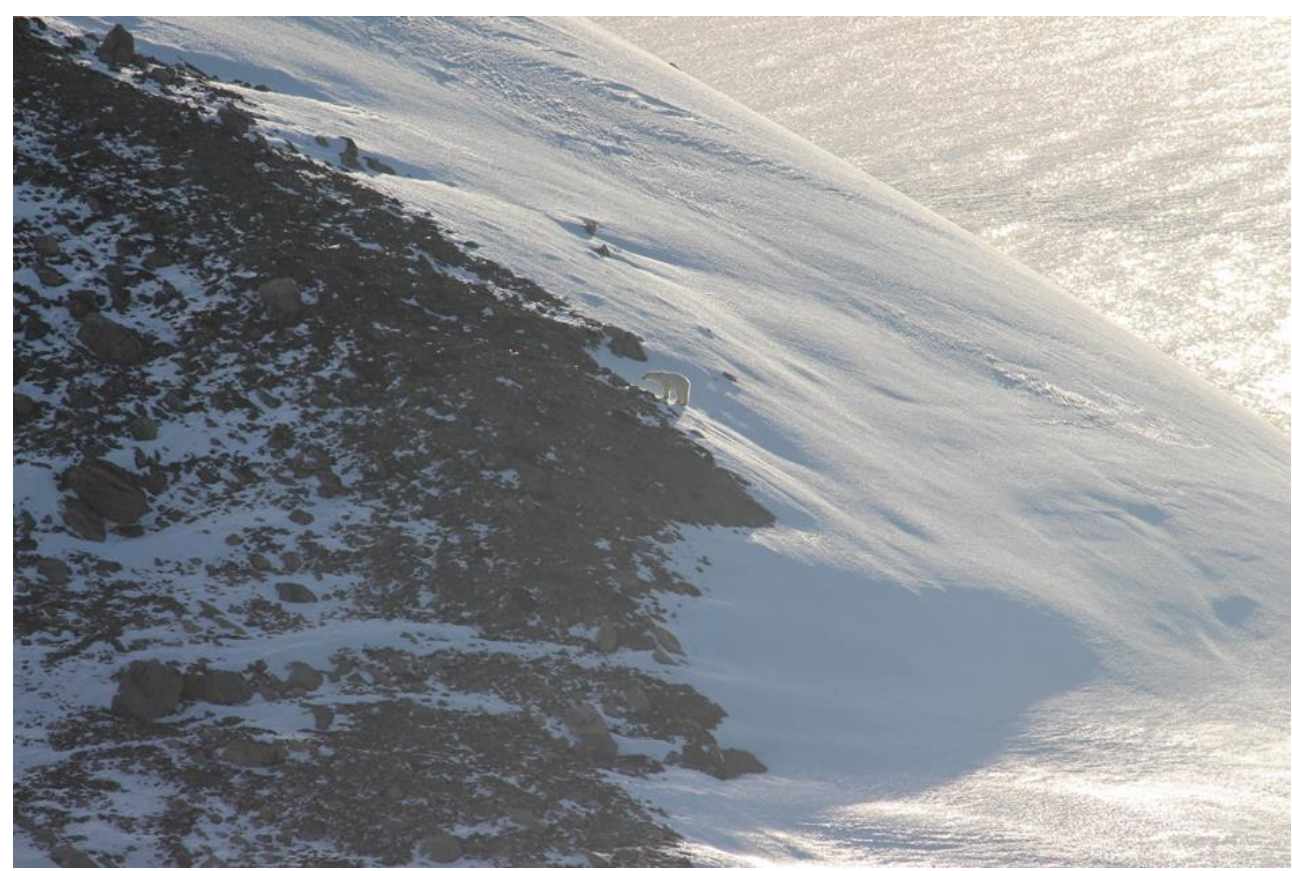

Figure 5. A grown polar bear in the center of the photo running along the same hill side as on Figure 4.

\section{CONCLUSIONS}

The geometrical design rules for berm breakwaters presented by Van der Meer and Sigurdarson 2016, enable the designer of breakwaters and revetments to make different design proposals for his project, proposals that can be weighted and compared in cost.

With the geometrical design rules for berm breakwaters it was possible to make different design options based on different availability of sizes of armourstone. In the first phase of the study the design wave height was established as $\mathrm{H}_{\mathrm{sD}}=4.4 \mathrm{~m}$. There was practically no information about a likely size distribution of armourstone from a dedicated armourstone quarry. The different design options covered the full range of the stability parameter $\mathrm{H}_{\mathrm{sD}} / \Delta \mathrm{D}_{\mathrm{n} 50}$ from 1.7 to 3.0 which corresponds to armourstone classes ranging from 5-15 $\mathrm{t}$ down to 1-3 t. Based on limited information on possible yield from a dedicated quarry for the project the study concluded the largest stone class could be chosen as 2-6 t or even larger.

\section{REFERENCES}

Sigurdarson, S. and J.W. van der Meer. 2015. Design and construction of berm breakwaters. Proceedings of Coastal Structures 2015, ASCE.

Sigurdarson, S., J.W. van der Meer, E. Bijl, Yang Sihan, Tang Qiaoliang, Zhang Xiaoqiang, James KS Goh and D. Heijboer. 2014. Icelandic-type berm breakwater for the Hambantota artificial island revetment, application of geometrical design rules. Proceedings of $34^{\text {th }}$ Conference on Coastal Engineering, ASCE.

Sigurdarson, S. and J.W. van der Meer. 2013. Design of berm breakwaters, recession, overtopping and reflection. Proceedings of Coasts, Marine Structures and Breakwaters 2013, ICE.

Sigurdarson, S. and J.W. van der Meer, 2012. Wave overtopping at berm breakwaters in line with EurOtop. Proceedings of $33^{\text {rd }}$ Conference on Coastal Engineering, ASCE.

Van der Meer, J.W. and S. Sigurdarson. 2016. Design and Construction of Berm Breakwaters. World Scientific. Advanced Series on Ocean Engineering, Volume 40. ISBN 978-981-4749-60-2.

Van der Meer, J.W. and S. Sigurdarson, 2014. Geometrical design of berm breakwaters, Proceedings of $34^{\text {th }}$ Conference on Coastal Engineering, ASCE. 